\title{
INNOVATION SYSTEMS IN A GLOBAL ECONOMY
}

\author{
CRIC, The University of Manchester
}

\author{
Daniele Archibugi, Jeremy Howells \\ \& Jonathon Michie \\ CRIC Discussion Paper No 18 \\ August 1998
}
Published by: Centre for Research on Innovation and Competition The University of Manchester
Tom Lupton Suite University Precinct Centre Oxford Road, Manchester M13 9QH


Dr Jeremy Howells is a Senior Research Fellow, working part time at CRIC and part time at PREST. He has written and co-authored several books on research and innovation, his latest book being 'Technology, Innovation and Competitiveness' with J Michie.

Professor Jonathon Michie is in the Department of Management at Birbeck College, University of London. He is also an Honorary Associate Fellow of CRIC.

Daniele Archibugi studied for a PhD at SPRU in Brighton and is now Research Director at the ISRDS-CNR in Rome. 


\section{ABSTRACT \\ Innovation Systems in a Global Economy \\ Daniele Archibugi, ${ }^{1}$ Jeremy Howells ${ }^{2}$ and Jonathan Michie $^{3}$}

There is increasing emphasis being put on the need to be 'internationally competitive'. This imperative is being driven, it is argued, by the globalisation of economic and corporate life. This 'globalisation' is the subject of a burgeoning academic literature. To achieve and maintain the necessary competitive edge requires companies to be innovative, technologically dynamic, and organisationally efficient - in a dynamic, not just static sense. There is a literature on systems of innovation analysing such requirements, how they have been met in practise in different contexts up until now, and what the implications are for policy. However, these two literatures - on systems of innovation and globalisation - have developed quite independently. The purpose of the current paper is to discuss the implications of each for the other. Far from transcending national systems of innovation, current globalisation processes are shown to have a symbiotic relation to such systems. 


\section{Introduction}

Increasing attention is being paid within academic, business and public policy circles to the questions of why, how and where technological innovations are generated, and then successfully diffused and developed. Within academia there are two separate, but closely connected bodies of literature on the sources and nature of new technologies. The first set is focused on the similarities and differences in the organisation of innovative activities at the national level, whilst the second group focuses on the role of globalisation in shaping technological change. The purpose of the current paper is to synthesis these two literatures with the aim of firstly testing to what extent the findings in each case survive - or are perhaps enhanced - when faced with the results from the other literature; and secondly to consider what the implications would be from such a synthesis for our understanding of how innovation systems operate within the evolving global - or international - economy.

Briefly, the first body of literature referred to above stresses that a proper understanding of technological developments, and their diffusion and dissemination throughout the economy and society, requires us to also understand the social fabric that shapes these developments and within which they are embedded. Over the last decade, the notion of systems of innovation - local, regional, sectoral or national - has been widely, and we would argue successfully, used to map and explain the interactions between agents that generate and use technology.

The second body of literature has studied how innovation interacts with economic and social globalisation. The debate on globalisation has flourished over the last decade and a large number of themes connected to it have been investigated. Trade, production, finance, culture, media, and many other fields have been scrutinised from the viewpoint of globalisation. The issue of technological change has been at the core of these debates on globalisation, and rightly so. On the one hand technology is a vehicle for the diffusion of information and knowledge across borders; on the other hand, technological developments have themselves been stimulated by the globalisation of markets. 
As indicated above, the purpose of the current article is to study the interplay between these national and global forces shaping technological change. It builds on the previous collaborative work of the three authors, as well as on the related work by other authors, some of which has been published in a series of books we have edited. ${ }^{4}$ This article attempts to clarify and analyse the key concepts that are addressed in more detail within this literature. In so doing we aim to draw out the key policy implications that would arise from a synthesis of what has been described above as a dual, but interrelated literature. The first part of the article is therefore devoted to outlining the origin of, and latest developments in, the systems of innovation approach; we then turn to consider more specifically the implications of economic and technological globalisation for the operation and analysis of systems of innovation.

\section{The origin of the 'system of innovation' approach}

The 'systems of innovation' approach has developed and evolved since its initial appearance in the form of the 'national systems of innovation' (NSI) studies presented by Freeman, Lundvall and Nelson. ${ }^{5}$ Chris Freeman was among the first to use the concept to help describe and interpret the performance of Japan over the post-war period. He identified a number of vital and distinctive elements in its national system of innovation to which could be attributed its success in terms of innovation and economic growth. ${ }^{6}$ It has subsequently been applied in a number of different contexts, many of which have been outside the original focus of a national setting. Thus, although the national focus remains strong, and rightly so, it has been accompanied by studies seeking to analyse the notion of systems of innovation at an international (or pan-national) level and at a sub-national scale.

Studies have also examined the systems of innovation approach within the context of a sectoral or technology perspective. Thus Bo Carlsson has developed what has become termed the 'technological systems' approach, indicating that systems can be specific to particular technology fields or sectors ${ }^{7}$. Sectors and technologies do matter and have their own dynamic. But as argued by Nelson, it is also the case that "nationhood matters and has a pervasive influence' ${ }^{8}$ Sectors and technological systems within a nation have a powerful shaping influence on the structure and dynamic of a national innovation system, whilst national contexts have important influences on sectoral conditioning and performance. Thus, prior institutional endowments of a national system may help or hinder innovative activity and 
performance within particular sectors of a national economy. ${ }^{9}$ The concepts of national (or spatially bounded) systems of innovation and technology systems (or sectoral innovation systems) should not be seen as mutually exclusive. Indeed, establishing the interrelationships between the two can yield valuable insights into the wider systems of innovation approach. ${ }^{10}$

\section{Some definitions and concepts}

Much of the literature on systems of innovation, and more especially on national systems of innovation, has been covered in an excellent review by Edquist, which draws on earlier valuable discussion and reviews by Lundvall, Nelson and Rosenberg, and Freeman. ${ }^{11}$ However, certain preliminaries in terms of definitions and concepts are useful here for two reasons. Firstly, they form the basis of the subsequent discussion, and secondly, such a discussion highlights areas that may prove particularly profitable in terms of future work within the 'systems of innovation' research area.

Chris Freeman defined the concept as the network of institutions in the public and private sectors whose activities and interactions initiate, import, modify and diffuse new technologies'. ${ }^{12}$ Lundvall makes a distinction between a narrow and broad definition of a system of innovation. ${ }^{13}$ His narrow definition would include 'organisations and institutions involved in searching and exploring - such as R\&D departments, technological institutes and universities'. His broader definition would include 'all parts and aspects of the economic structure and the institutional set-up affecting learning as well as searching and exploring - the production system, the marketing system and the system of finance present themselves as subsystems in which learning takes place'.

In respect of the 'national' element, Lundvall stresses that this is not as clear-cut as is often assumed. ${ }^{14}$ The concept of 'national systems of innovation' has two dimensions: the nationalcultural and the Ėtatist-political. The ideal, abstract nation state where these two dimensions coincide controlled by one central state authority is difficult, if not impossible, to find in the real world. Moreover, this nationally bounded view, at least in geographical terms, has been loosened over time. The approach has now been widened and developed to include systems of innovation that are sectoral in dimension and those that are at a different geographical scale, 
both above in terms of what Freeman coined 'upper' regions ('triad' and continental regions), and below in relation to regional ${ }^{15}$ and local systems.

Regarding the term 'innovation', Edquist has stressed the ambiguity and wide variation in its use. ${ }^{16}$ Thus, Nelson and Rosenberg, and Carlsson and Stankiewicz, have tended to adopt narrower definitions, mainly (though not wholly) centred on technological innovations, whilst Lundvall seeks to include non-technological innovations, in particular institutional innovations. ${ }^{17}$ In his analysis of the Japanese innovation system, Freeman also emphasised the role of social and educational innovations, whilst Carlsson and Stankiewicz, in adopting Dosi's definition of innovation would also seem to include the emergence and development of new organisational set-ups. ${ }^{18}$

Lastly, discussion of the term 'system' has been strangely limited. Lundvall (1992a, p.2) is the most specific here, although still brief. ${ }^{19}$ Thus he makes a short reference to Boulding's definition of a system as 'anything not in chaos' as well as noting that a system 'is constituted by a number of elements and by the relationships between these elements' ${ }^{20}$ Little reference is made to earlier work on systems theory, or to how this literature originally defined, or perceived, a system. ${ }^{21}$

\section{The evolution and development of the concept}

Edquist reviewed the different elements and perspectives of the systems of innovation literature, in particular concentrating on the commonalities of the different approaches. ${ }^{22}$ More specifically, he outlines nine common characteristics of the systems of innovation approach and their advantages and problems. These core characteristics of systems of innovation approaches are: innovation and learning; their holistic and interdisciplinary nature; the natural inclusion of a historical perspective; differences between systems and non-optimality; their emphasis on interdependence and non-linearity; the incorporation of product technologies and organisational innovations; the central role of institutions in the systems of innovation approach; their conceptually diffuse nature; and the focus of the systems of innovation literature on conceptual constructs rather than on a more deeply-rooted theoretical framework. ${ }^{23}$ 
Edquist's contribution is important because it seeks to determine common foundations of a 'systems of innovation' approach and seeks to build common frames of reference. It also highlights the high degree of diversity of approaches. While at one level this diversity is problematic, it might also explain why the approach has provoked such interest and produced such a rich vein of inter-disciplinary work. Seeking to harmonise and more closely delimit definitions and concepts may now be necessary if the research programme is to develop further; on the other hand it is important to avoid the danger of foreclosing on ideas too early on. The following sections focus on a number of these ideas and key issues in current systems of innovation thinking.

\subsection{The role of learning in an innovation system}

Although Lundvall noted the role that learning played in binding together production and innovation in a national system of innovation, ${ }^{24}$ and sought to further emphasis the importance of learning in his 1992 discourse on the notion of national systems of innovation, ${ }^{25}$ it has been only recently that he has sought to develop the role of learning and put it at the core of the national systems of innovation construct. ${ }^{26}$ In these latter works he has stressed the role of learning in new and competitive national systems of innovation and especially the process of interactive learning. ${ }^{27}$

Learning is important in Lundvall's conception of systems of innovation because it is a key element in both the dynamic of the system and as a key agent in binding the whole system together. Thus, 'many different sectors and segments of the economy contribute to the overall process of interactive learning and the specificity of the elements, as well as the linkages and modes of interaction between them, are crucial for the rate and direction of technical change'. ${ }^{28}$

Learning thus plays a major role in the development of the system, whilst forming the key element in its connectivity. In this framework learning takes place at all levels from the individual, through to the firm and organisation, on to inter-firm and inter-organisational learning, institutional learning, ${ }^{29}$ cross institutional learning, and on through to the whole system - the 'learning economy'. Obviously the learning process involves a clear interactive 
and collective dimension. There are also inter-firm and more general institutional routines that can be set up through this interactive learning process. ${ }^{30}$ However, it is much harder to ascribe collections of firms, organisations and institutions as having a single, clear cognitive process, involving both a decision-making and memory function. The notion that what is learnt will be exactly the same for each individual, firm, organisation and institution is difficult to accept. ${ }^{31}$

\subsection{The evolutionary nature of systems of innovation}

There have been important attempts recently to develop the latent evolutionary aspects of the national systems of innovation concept. This has been done by outlining the value of evolutionary concepts in providing a stronger theoretical underpinning to the national systems of innovation model, ${ }^{32}$ and also by highlighting the utility of evolutionary concepts in helping to define what is meant by a national system of innovation. ${ }^{33}$

Although such evolutionary approaches have, a posteriori, helped to explain the dynamic aspects of systems of innovation they have provided very little, if any, predictive insights into how national systems of innovation might develop in the future. While Galli and Teubal have outlined what they see as paradigmatic changes and structural adjustments of national systems of innovation since the late 1970s, this approach does not directly draw upon an evolutionary perspective, nor does it suggest what new transition stages will appear or when. ${ }^{34}$ The lack of any predictive element within systems of innovation thinking is a reflection of the fact that it represents a partial model rather than claiming to be a complete formal theory. ${ }^{35}$ As yet, although the systems of innovation approach stresses historical processes, it has yielded few insights into the dynamics of the innovation process.

\subsection{Systems as flows, links and networks}

Although there is a general stress on 'interaction' and more specifically 'interactive learning' by Lundvall, ${ }^{36}$ and on knowledge flows by, for example, David and Foray, ${ }^{37}$ there are very few references to, let alone analysis of, the specific nature of these interactions in terms of flows and linkages connecting the actors in a network. This neglect of linkages and flows is strange, given that networks form one of the cornerstones in defining a system. ${ }^{38}$ 
There are, of course, notable exceptions. An important analysis of the flows within and across systems of innovation is supplied by the literature on inter-industry technology flows. ${ }^{39}$ This literature has managed to map to what extent certain industries benefit from the innovations generated by 'upstream' suppliers which in turn has indicated the degree of sectoral integration amongst industries. This body of literature has also had the notable advantage of being able to quantitatively map these flows. However, this approach has so far not been specifically integrated into the framework of innovation systems.

As discussed above, the concept of innovation systems is much wider than inter-industry technology flows. Firstly, because it includes also flows which are not necessarily intersectoral, such as knowledge and information flows that occur within firms belonging to the same industry. Secondly, because it takes into account also the transfer of tacit and noncodified knowledge, which is not captured by the indicators that have so far been used to map inter-industry technology flows. ${ }^{40}$ Thirdly, because the innovation systems approach also considers flows which occur between different types of organisations and institutions, including firms, agencies and government establishments.

One attempt to take into account an extended framework is provided by Galli and Teubal, who briefly mention linkages in their commentary on the main components of systems of innovation. ${ }^{41}$ Another is the analysis by Andersen ${ }^{42}$ of innovation systems using firstly, 'primitive graph techniques', ${ }^{43}$ and secondly, simulation modelling to describe vertical relationships in innovations, although as yet these techniques outlined by Andersen have not been empirically applied or tested. ${ }^{44}$

This relative under analysis of linkages and flows within the systems of innovation literature represents an important barrier to the further conceptual development of the approach for three key reasons:

1. Firstly, the way that networks and, in turn, systems are usually defined is by the volume and characteristics of the linkages that bind them together. In short, systems are made up of the interactions between the actors or nodes in a system. Without any interaction between actors and nodes it is difficult to accept that a system exists.

2. Following on from this, flows and linkages in a system are also critical in defining an innovation system, and the way in which it functions and operates. 
3. Lastly, a key element in gaining an adequate dynamic and evolutionary perspective on a system is by analysing the changing flow and linkage patterns between the actors and institutions that compose a system. Although the nature of the actors and institutions can change and forms an essential dynamic in itself, this change is also reflected and altered by the changing relationships between such actors and institutions.

Thus, growth in a system can be characterised in a number of different ways. In relation to an innovation system, growth could be confined within the individual elements or actors (the firms or other organisations), or it could result from increased flows between the elements of the system. Similarly, all the growth in a system could reside within the system if it was fully 'closed' but could flow out of it, to varying degrees, if it was an 'open' system. Even changing these two simple dimensions, in relation to growth and linkages within an innovation system, can alter its growth characteristics and dynamics radically. The fact that these aspects are as yet relatively under researched may reflect the 'youthfulness' of the systems of innovation research programme, and also the relative difficulty of trying to measure such innovation flows and linkages in a dynamic context. Nevertheless, a more detailed analysis of innovation flows and linkages is certainly required if an adequate model (or set of models) of innovation systems is to be provided.

\subsection{Systems as innovation 'task environments' for firms}

Another rich seam for future research within the systems of innovation literature is a bottomup perspective of how national/sectoral systems of innovation may condition and influence the innovation decision-making and behaviour of firms. The systems of innovation approach tends, by its very nature, to take a 'top-down' view of firms' innovative activity. ${ }^{45}$ There is still much to be learned regarding how firms respond to, and interact with, the innovation system (national, sectoral or otherwise) at any point in time.

Much of the discussion that does indirectly refer to firm-level action, de facto considers individual firms as simply reacting to changes that are occurring within the wider system - or within the more specific network or institutional level. There has been little discussion about firm behaviour and technology strategy in terms of its relationship with systems of innovation 
approaches, even though firms represent important actors within the innovation system. Exceptions include Carlsson and Stankiewicz who consider the issue of individual firm behaviour in their outline of a technology system. ${ }^{46}$ Ehrnberg and Jacobsson also discuss firmlevel strategy, although mainly within the context of a firm's response to technological discontinuities. ${ }^{47}$

The key issue here is how much the presence (or indeed absence) of a national or sectoral system of innovation may affect the innovation behaviour, actions and outcomes of firms. Yet the systems of innovation research programme has, as yet, had little impact on the technology strategy and management literature. Certainly an empirical analysis of the innovative performance of firms in weak and strong national and/or sectoral systems of innovation might provide an interesting new avenue of research.

\subsection{The empirical analysis of systems of innovation}

Archibugi and Pianta, and Patel and Pavitt, set out a list of indicators that might be used to 'measure' a national system of innovation, ${ }^{48}$ and these have been taken up to varying degrees by a number of subsequent studies. ${ }^{49}$ Recently, a valuable set of empirically-based studies, using aggregate data sets on a national and international basis, have outlined national patterns of innovative activity and performance. ${ }^{50}$

However, on a more micro, firm or organisational level, most acknowledge that there remains a gap between theoretical developments and empirical analysis, and researchers are still at the stage of discussing and defining which analytical tools and methods might most profitably be used in empirical studies to bridge this gap. The work by Andersen, noted above, using graph techniques and simulation modelling appears to be a promising avenue of empirical work along these lines. However, more certainly needs to be done to review, systematise and apply existing empirical studies covering these issues to systems of innovation work.

Perhaps the biggest task that remains in the development of the systems of innovation approach remains in providing a better linkage between the more aggregate, macro level studies and the micro level analysis of firm relationships and behaviour. In terms of the 
conceptual framework of the approach it is at this 'meta' level where the role of institutions and wider organisational networks is crucial, and where further empirical work beckons.

\section{What is Globalisation?}

It is certainly telling that the debate on national innovation systems has developed in an age when the forces of globalisation are transforming economic life. It seems that the pressures of globalisation have generated a new concern regarding the role played by nation-specific factors. The term 'globalisation', however, has often been used in a rather general and unspecified way, rendering much of the resultant analytical and policy conclusions rather tenuous. In the context of the current discussion, the recent literature has used the concept in, at least, two different ways. 51

The first is related to the mapping of global factors in economic and social life. Global factors have always influenced the performance of local and/or national communities, but the reason why we talk about globalisation in this age is based on the assumption (right or wrong) that the importance of world-wide relations has increased both quantitatively and qualitatively. To map the resulting global transformations requires the ability to identify the dynamic context which is leading, according to some authors, to a dramatic increase of cross-border flows of information, knowledge, commodities and capital.

The second meaning of globalisation is linked to policy analysis. For example, the term 'globalisation' is often used implicitly, if not explicitly, as equivalent to the term 'liberalisation'. This is however inappropriate since globalisation is mainly a descriptive concept while liberalisation has a prescriptive meaning. In a related context, the debate on globalisation has often collided with the assessment of the effectiveness of government policies. $^{52}$ It has been argued that globalisation is reducing the impact of certain policy instruments, for example interest rate changes, since all national public policies act under international constrains. Certainly, globalisation is putting new pressures on nation states which often lead to unwelcome outcomes. However, to influence these outcomes, a different mix of policies may be needed. While certain traditional macroeconomic policies, such as those based on exchange rates and interest rates, may have lost a significant part of their 
effectiveness, other kinds of policies, such as industrial policies, may be becoming increasingly important if governments are to pursue their own objectives.

Policies directed towards competence (such as those favouring training, education, the acquisition of managerial skills, and encouraging technological change) become crucial instruments to allow national communities to take advantage of - or at least protect themselves in the face of - the processes of globalisation. One implication of this is, therefore, that policies aimed at the creation of technological competence are needed to strengthen national competitiveness and to preserve local wellbeing. 


\section{The boundaries of innovation systems in a global economy}

Technological change provides a privileged viewpoint from which to understand the dynamics of globalisation. New technologies have always been international in scope; the transmission of knowledge has never respected states' borders. There is a complex interplay between technological change and globalisation. On the one hand, new technologies act as a powerful vehicle for the diffusion of information across distant communities. For example, it would be difficult to imagine the current globalisation of financial markets without the existence of the new information and communication technologies, since they have made it possible to conduct instant transactions across the world. On the other hand, the process of generating and diffusing new technologies has been moulded and strengthened by the flows of individuals, commodities and capital. This has created a circular process whereby technology has facilitated globalisation and vice versa.

The key questions arising from this are as follows: i) Firstly, if the globalisation of technological innovation is occurring, will it lead to the eventual dissolution of national systems of innovation?53 ii) Secondly, will national systems of innovation converge towards more similar structures because of the forces of globalisation? iii) And thirdly, is globalisation eroding the importance of innovation policies carried out at the national level?

It is often argued that globalisation is making spatially bounded systems less relevant. This implies that technology-based innovation systems (such as semiconductors) will be dominated by common technological regimes, regardless of the spatial location in which the connected production will take place. It is therefore possible to compare two approaches: the first stresses the importance of spatially-bounded (local, regional or national) innovation systems, but pays less attention to the differences between neighbouring firms operating in different industries. The second approach stresses instead the role of global factors in the making of innovation systems, but has the consequent danger of overlooking location-specific aspects of this process.

As already stressed, we need to go beyond an either/or debate, and try to identify the relative roles of regional, national, sectoral and global factors in shaping innovation systems. The 
innovation systems concept is itself flexible enough to allow us to take into account the relative importance of each of these factors; some criteria can be identified in order to assess when and how local or global factors will prevail and how they will interact.

First, globalisation makes easier the transmission of best-practice techniques across countries. Semiconductors, antibiotics and new materials are based upon similar and shared knowledge across the globe. This, however, does not imply an automatic process of acquisition of knowledge since learning is neither instant nor automatic.

Second, globalisation does not act only as the vehicle of best-practice techniques; it is also a vehicle for the international flow of goods and services. In order to survive in a competitive environment, firms are forced to find their own market niches where they can exploit their own competitive advantages. Often these niches rely heavily on endogenous capabilities. The problem that firms and nations have to face is not simply in being able to access the basic knowledge for semiconductors, new molecules or materials, but also to be able to use this knowledge to generate competitive products.

Third, there are location-specific advantages which have not lost their importance. Foreign direct investment by multinational corporations are increasingly sensitive to exploiting the locality-specific advantages associated with certain areas or regions. Thus Cantwell stresses that globalisation has made even more important the role of nation-specific assets for multinational corporations. ${ }^{54}$

Fourth, there is increasing evidence that the international distribution of production and of technological capabilities is becoming more sectorally differentiated. The process of international integration is leading to an increased division of labour and this implies that each country is focusing on selected industries and relying on trade for others. Even if the manufacture of semiconductors, for example, is becoming increasingly similar across countries, this does not imply that all countries are active in semiconductor production.

\section{The role of multinational corporations in the global economy}


Multinational enterprises have a major and visible influence on national systems of innovation. However, it is not clear whether large multinational firms have more influence on a national system of innovation, or whether it is more nationally-oriented, medium-sized companies that are more strongly embedded in the national system that will have a greater impact. Valuable work on this issue has been undertaken by Chesnais, and more recently by Barré in his analysis of the relationship of multinational firms' strategies and national innovation systems. ${ }^{55}$ However, as Barré admits, his work has been restricted by the nature and availability of the data that could be deployed and the assumptions behind their use. ${ }^{56}$

Pavitt and Patel provide significant evidence on three aspects of the innovative behaviour of large firms: $:^{57}$ first, multinational corporations are rather reluctant to locate technological activities in host countries. Core competences, including R\&D and innovation centres, are still heavily concentrated in the companies' home countries. Second, traditional industries are, in proportion, more internationalised than high-tech industries. This result is certainly significant since it indicates that knowledge-intensive productions are more dependent on territorially bounded competences. Third, when companies decide to move part of their R\&D and innovation centres abroad, they generally select the fields of excellence of the host countries. In other words, companies are more likely to go abroad to exploit the national capabilities of other countries rather than to simply expand their own core competences. This last point is confirmed by the survey results reported by Dunning and Wymbs which document how firms augment their technological advantages from foreign sources. ${ }^{58}$

\section{Conclusions}

We live in a turbulent world dominated by an increasing rate of technological change. Economic agents, including firms and governments, are forced to adapt to technological change in order to survive in a competitive environment. This article has attempted to identify some of the emerging patterns in the resulting organisation of innovative activities. The notion of innovation systems proves to be a hugely useful tool in understanding how innovative activities are generated and disseminated, and what their impact is on economic and social life. ${ }^{59}$ What is required is an evaluation of the notion of innovation systems in the context of current trends in the globalisation of economic, as well as technological, activities. When this is done it becomes clear that globalisation does not make local, regional or national systems 
redundant. On the contrary, such systems of innovation play a key role in shaping the global pattern of corporate technological activity. 


\section{Notes and references}

${ }^{1}$ ISRDS-CNR, Via Cesare De Lollis 12, I-00185, Rome

${ }^{2}$ CRIC and PREST, at University of Manchester and UMIST

${ }^{3}$ Department of Management, Birkbeck College, University of London

${ }^{4}$ See D. Archibugi, J. Howells, and J. Michie (eds), Innovation Systems in a Global Economy (Cambridge, Cambridge University Press, 1998); D. Archibugi and J. Michie (eds.), Technology, Globalisation and Economic Performance (Cambridge, Cambridge University Press, 1997); D. Archibugi and J. Michie (eds.), Trade, Growth and Technical Change (Cambridge, Cambridge University Press, 1998); and J. Howells and J. Michie (eds.) Technology, Innovation and Competitiveness (Cheltenham, Edward Elgar, 1997).

${ }^{5}$ See C. Freeman, Technology Policy and Economic Performance: Lessons from Japan (London, Frances Pinter, 1987); C. Freeman, 'Japan: a new national system of innovation?', in G. Dosi, C. Freeman, R. Nelson, G. Silverberg, and L. Soete (eds.), Technological Change and Economic Theory (London, Pinter, 1988); C. Freeman, 'The National System of Innovation in historical perspective', Cambridge Journal of Economics, 19, 1995, 5-24; (Reprinted in D. Archibugi and J. Michie (eds.), Technology, Globalisation and Economic Performance, Cambridge, Cambridge University Press, 1997); B.-Å. Lundvall, 'Innovation as an interactive process. From user-producer interaction to National Systems of Innovation', in G. Dosi, C. Freeman, R. Nelson, G. Silverberg and L. Soete, L. (eds.), Technological Change and Economic Theory (London, Pinter, 1988); B.-Å. Lundvall (ed.), National Systems of Innovation: Towards a Theory of Innovation and Interactive Learning (London, Pinter, 1992); and R. R. Nelson R. R. (ed.), National Innovation Systems: A Comparative Analysis (New York, Oxford University Press, 1993).

${ }^{6}$ C. Freeman, 'Japan: a new national system of innovation?', in G. Dosi, C. Freeman, R. Nelson, G. Silverberg, and L. Soete (eds.), Technological Change and Economic Theory (London, Pinter, 1988), p.338

${ }^{7}$ B. Carlsson (ed.). Technological Systems and Economic Performance: The Case of Factory Automation (Dordrecht, Kluwer, 1995).

${ }^{8}$ R. R Nelson, 'A retrospective', in Nelson R. R. (ed.), National Innovation Systems: A Comparative Analysis (New York, Oxford University Press, 1993), p.518.

9 J. Howells and I. Neary, Intervention and Technological Innovation: Government and the Pharmaceutical Industry in the UK (Basingstoke, Macmillan, 1995), p.245 
D. Archibugi and J. Michie, 'Technological globalisation and national systems of innovation: an introduction', in D. Archibugi and J. Michie (eds.) Technology, Globalisation and Economic Performance (Cambridge, Cambridge University Press, 1997), p.13

${ }^{11}$ C. Edquist, 'Systems of innovation approaches. Their emergence and characteristics', in: Edquist (ed.) Systems of Innovation: Technologies, Institutions and Organizations (London, Pinter, 1997). This draws on earlier valuable discussion and reviews by B.-Å. Lundvall, 'Introduction', in: Lundvall (ed.) National Systems of Innovation: Towards a Theory of Innovation and Interactive Learning (London, Pinter, 1992); R. R. Nelson and N. Rosenberg, 'Technical innovation and national systems', in: Nelson (ed.) National Innovation Systems: A Comparative Analysis (New York, Oxford University Press, 1993); and C. Freeman, 'The National System of Innovation in historical perspective', Cambridge Journal of Economics, 19, 1995, 5-24, reprinted in D. Archibugi and J. Michie (eds), Technology, Globalisation and Economic Performance (Cambridge, Cambridge University Press, 1997)

${ }^{12}$ C. Freeman, Technology Policy and Economic Performance: Lessons from Japan (London, Frances Pinter, 1987), p.1

${ }^{13}$ B.-Å. Lundvall, 'Introduction', in: Lundvall (ed.) National Systems of Innovation: Towards a Theory of Innovation and Interactive Learning (London, Pinter, 1992), p.12

${ }^{14}$ B.-Å. Lundvall, 'Introduction', in: Lundvall (ed.) National Systems of Innovation: Towards a Theory of Innovation and Interactive Learning (London, Pinter, 1992), pp.2-3

${ }^{15}$ C. Freeman, 'The National System of Innovation in historical perspective', Cambridge Journal of Economics, 19, 1995, 5-24, defines these as 'nether' regions to avoid the confusion of some commentators who use the world 'region' to denote triad or continental regions (p.21).

${ }^{16}$ C. Edquist, 'Systems of innovation approaches. Their emergence and characteristics', in: C. Edquist (ed.) Systems of Innovation: Technologies, Institutions and Organizations (London, Pinter, 1997), p.10

${ }^{17}$ R. R. Nelson and N. Rosenberg, 'Technical innovation and national systems', in Nelson (ed.) National Innovation Systems: A Comparative Analysis (New York, Oxford University Press, 1993) and B. Carlsson and R. Stankiewicz, 'On the nature, function and composition of technological systems', in B. Carlsson (ed.), Technological Systems and Economic Performance: The Case of Factory Automation (Dordrecht, Kluwer, 1995) have tended to adopt narrower definitions, mainly (though not wholly) centred on technological 
innovations, whilst B.-Å. Lundvall, 'Introduction', in Lundvall (ed.) National Systems of Innovation: Towards a Theory of Innovation and Interactive Learning (London, Pinter, 1992) seeks to include non-technological innovations, in particular institutional innovations; this point is further developed in B.-A. Lundvall, 'Technology policy in the learning economy', in D. Archibugi, J. Howells, and J. Michie (eds), Innovation Systems in a Global Economy (Cambridge, Cambridge University Press, 1998).

${ }^{18}$ See C. Freeman, 'Japan: a new national system of innovation?', in: G. Dosi, C., Freeman, R. Nelson, G. Silverberg, L. and Soete (eds.), Technological Change and Economic Theory (London, Pinter, 1988) pp.33941; B. Carlsson and R. Stankiewicz, 'On the nature, function and composition of technological systems', in: B. Carlsson (ed.), Technological Systems and Economic Performance: The Case of Factory Automation, (Dordrecht, Kluwer, 1995), p.28; and G. Dosi, 'Sources, procedures and microeconomic effects of innovation', Journal of Economic Literature, 36, 1988, 1126-71.

${ }^{19}$ B.-Å. Lundvall, 'Introduction', in: Lundvall (ed.) National Systems of Innovation: Towards a Theory of Innovation and Interactive Learning (London, Pinter, 1992), p.2

${ }^{20}$ See K. E. Boulding, The World as a Total System (Beverly Hills, CA, Sage, 1985), p.2

${ }^{21}$ See, for example, A. D. Hall and R. E. Fagen, 'Definition of system', General Systems Yearbook, 1, 1956, $18-28$.

${ }^{22}$ C. Edquist, 'Systems of innovation approaches. Their emergence and characteristics', in: Edquist (ed.) Systems of Innovation: Technologies, Institutions and Organizations (London, Pinter, 1997)

${ }^{23}$ C. Edquist, C., 'Systems of innovation approaches. Their emergence and characteristics', in: Edquist (ed.) Systems of Innovation: Technologies, Institutions and Organizations (London, Pinter, 1997), pp.16-29

${ }^{24}$ B.-Å. Lundvall, 'Innovation as an interactive process. From user-producer interaction to National Systems of Innovation', in Dosi, G., Freeman, C. Nelson, R. Silverberg, G. and Soete, L. (eds.), Technological Change and Economic Theory (London, Pinter, 1988), p.362

${ }^{25}$ B.-Å. Lundvall, 'Introduction', in: Lundvall (ed.) National Systems of Innovation: Towards a Theory of Innovation and Interactive Learning (London, Pinter, 1992) pp.9-11

${ }^{26}$ B.-Å. Lundvall, 'The global unemployment problem and national systems of innovation', in: O'Doherty, D. P. (ed.) Globalisation, Networking and Small Firm Innovation, (London, Graham \& Trotman, 1995); B.-Å. Lundvall, 'Technology policy in the learning economy', in: Archibugi, D., Howells, J. and Michie, J. (eds), 
Innovation Systems in a Global Economy (Cambridge, Cambridge University Press, 1998); and Lundvall, B.Å. and Johnson, B.A. 1995. The learning economy Journal of Industry Studies, 1: 23-41.

${ }^{27}$ B.-Å. Lundvall,. 'The global unemployment problem and national systems of innovation', in: O'Doherty, D.

P. (ed.) Globalisation, Networking and Small Firm Innovation (London, Graham \& Trotman, 1995), p.39

${ }^{28}$ B.-Å. Lundvall, ‘The global unemployment problem and national systems of innovation’, in: O'Doherty, D.

P. (ed.) Globalisation, Networking and Small Firm Innovation (London, Graham \& Trotman, 1995), p.40

${ }^{29}$ On which, see Johnson, B. 1992. Institutional learning, in Lundvall (ed.) National Systems of Innovation: Towards a Theory of Innovation and Interactive Learning, London, Pinter

${ }^{30}$ Hodgson, G. 1988. Economics and Institutions, Cambridge, Polity Press.

31 See Antonelli, C. 1994. The Economics of Localized Technological Change and Industrial Change, Boston, Kluwer Academic Publisher.

${ }^{32}$ Saviotti, P. P. 1997. Innovation systems and evolutionary theories, in Edquist (ed.) Systems of Innovation: Technologies, Institutions and Organizations, London, Pinter

${ }^{33}$ McKelvey, M. 1997. Using evolutionary theory to define systems of innovation, in Edquist (ed.) Systems of Innovation: Technologies, Institutions and Organizations, London, Pinter

${ }^{34}$ Galli, R. and Teubal, M., 'Paradigmatic shifts in National Innovation Systems', in: Edquist (ed.) Systems of Innovation: Technologies, Institutions and Organizations (London, Pinter, 1997), pp.345-64

${ }^{35}$ Edquist, C. 1997. Systems of innovation approaches. Their emergence and characteristics, in Edquist (ed.) Systems of Innovation: Technologies, Institutions and Organizations, London, Pinter, pp.28-9

${ }^{36}$ Lundvall, B.-Å. 1992. Introduction, in Lundvall (ed.) National Systems of Innovation: Towards a Theory of Innovation and Interactive Learning, London, Pinter. See also Lundvall, B.-Å. and Johnson, B.A. 1995. The learning economy Journal of Industry Studies, 1: 23-41

${ }^{37}$ David, P. A. and Foray, D. 1995. Accessing and expanding the science and technology knowledge base, STI Review, n.16: 13-68; and David, P. A. and Foray, D. 1996. Information distribution and the growth of economically valuable knowledge: a rationale for technological infrastructure policies, in M. Teubal, D. Foray, M. Justman, and E. Zuscovitch (eds.) Technological Infrastructure Policy: An International Perspective, Dordrecht, Kluwer. 
${ }^{38}$ Saviotti, P. P. 1997. Innovation systems and evolutionary theories, in Edquist (ed.) Systems of Innovation: Technologies, Institutions and Organizations, London, Pinter, pp.193-5

${ }^{39}$ See Scherer, F. M. 1982. 'Inter-industry technology flows in the US', Research Policy, 11: 227-45; Pavitt, K. 1984. Sectoral Patterns of Technical Change, Research Policy, 13: 343-73; Archibugi, D. 1988. In search of a useful measure of technological innovation, Technological Forecasting and Social Change, 34: 253-77; and DeBresson, C. (ed.) 1996. Economic Interdependence and Innovative Activity: An Input-Output Analysis, Cheltenham, Edward Elgar.

${ }^{40}$ Howells, J. 1996. Tacit knowledge, innovation and technology transfer, Technology Analysis \& Strategic Management, 8: 91-106.

${ }^{41}$ Galli, R. and Teubal, M. 1997. Paradigmatic shifts in National Innovation Systems, in Edquist (ed.) Systems of Innovation: Technologies, Institutions and Organizations, London, Pinter, pp.347-8

${ }^{42}$ Andersen, S. E. 1992. User-producer relationships, national systems of innovation and internationalisation, in Lundvall (ed.) National Systems of Innovation: Towards a Theory of Innovation and Interactive Learning, London, Pinter; Andersen, S. E. 1996. From static structures to dynamics: specialization and innovative linkages, in DeBresson (ed.) Economic Interdependence and Innovative Activity: An Input-Output Analysis, Cheltenham, Edward Elgar; and Andersen, E. S. and Lundvall, B.-Å. 1997. National Innovation Systems and the dynamics of the division of labor, in Edquist (ed.) Systems of Innovation: Technologies, Institutions and Organizations, London, Pinter.

43 See, for example, Andersen, E. S. and Lundvall, B.-Å. 1997. National Innovation Systems and the dynamics of the division of labor, in Edquist (ed.) Systems of Innovation: Technologies, Institutions and Organizations, London, Pinter, p.243, and for an earlier attempt, Santarelli, E. 1995. Directed graph theory and the economic analysis of innovation, Metroeconomica, 46: 111-26.

44 Andersen, E. S. and Lundvall, B.-Å. 1997. National Innovation Systems and the dynamics of the division of labor, in Edquist (ed.) Systems of Innovation: Technologies, Institutions and Organizations, London, Pinter, p. 253

${ }^{45}$ See J. Howells, 'Regional systems of innovation?', in: Archibugi, D., Howells, J. and Michie, J. (eds) 1998. Innovation Systems in a Global Economy, Cambridge: Cambridge University Press 
${ }^{46}$ See Carlsson, B. and Stankiewicz, R., 'On the nature, function and composition of technological systems', in: Carlsson, B. (ed.), Technological Systems and Economic Performance: The Case of Factory Automation, (Dordrecht, Kluwer, 1995), pp.25-6. However, this is only within the context of variety and diversity. Also they appear to rather downplay the point by citing Alchian's argument that attention should be paid to distributions of economic behaviour rather than to the behaviour of the individual (Alchian, A. 1951. Uncertainty, evolution and economic theory, Journal of Political Economy, 68: 211-21). See also Metcalfe, J. S. 1989. Evolution and economic change, in Silberston, A. (ed.) Technology and Economic Progress, London, Macmillan, pp.59-66.

${ }^{47}$ Ehrnberg, E. and Jacobsson, S. 1997. Technological discontinuities and incumbents' performance: an analytical framework, in Edquist (ed.) Systems of Innovation: Technologies, Institutions and Organizations, London, Pinter, pp.320-6

${ }^{48}$ Archibugi, D. and Pianta, M. 1992. The Technological Specialization of Advanced Countries , Dordrecht, Kluwer; and Patel, P. and Pavitt, K. 1994. 'National Innovation Systems: why they are important, and how they might be measured and compared', Economics of Innovation and New Technology, 3: 77-95.

49 See, for example, Gassler, H. Fröhlich, J. and Kopcsa, A. 1996. Selective information on the National System of Innovation as an important input for the technology management of firms, International Journal of Technology Management, 11: 329-42.

${ }^{50}$ See P. Guerrieri, 'Patterns of national specialization in the global competitive environment', in: Archibugi, D., Howells, J. and Michie, J. (eds) 1998. Innovation Systems in a Global Economy, Cambridge: Cambridge University Press; and K. Pavitt and P. Patel, 'Global corporations and national systems of innovation: who dominates whom?', in: Archibugi, D., Howells, J. and Michie, J. (eds) 1998. Innovation Systems in a Global Economy, Cambridge: Cambridge University Press

${ }^{51}$ Paul Streeten, half in jest, provided a long list of different definitions of the term globalisation: Streeten, P. 1996. Governance of the Global Economy, paper presented at the International Conference 'Globalization and Citizenship', United Nations Research Institute for Social Development, Geneva, 9-11 December.

${ }^{52}$ See Michie, J. and Grieve Smith, J. (eds.) 1995. Managing the Global Economy, Oxford, Oxford University Press. 
${ }^{53}$ See, for example, the conclusions presented on this by Saviotti, P. P. 1997. Innovation systems and evolutionary theories, in Edquist (ed.) Systems of Innovation: Technologies, Institutions and Organizations, London, Pinter, p.196.

${ }^{54} \mathrm{~J}$. Cantwell, 'Innovation as the principal source of growth in the global economy', in: Archibugi, D., Howells, J. and Michie, J. (eds) 1998. Innovation Systems in a Global Economy, Cambridge: Cambridge University Press

${ }^{55} \mathrm{~F}$. Chesnais, 'National systems of innovation, foreign direct investment and the operations of multinational enterprises', in: Lundvall (ed.) National Systems of Innovation: Towards a Theory of Innovation and Interactive Learning, London, Pinter, and more recently by Barré, R. 1995. Relationships between multinational firms' technology strategies and national innovation systems: a model and empirical analysis, STI Review, 15: 201-22.

${ }^{56}$ Barré, R. 1995. Relationships between multinational firms' technology strategies and national innovation systems: a model and empirical analysis, STI Review, 15: 201-22, p.218

${ }^{57}$ K. Pavitt and P. Patel, 'Global corporations and national systems of innovation: who dominates whom?', in: Archibugi, D., Howells, J. and Michie, J. (eds) 1998. Innovation Systems in a Global Economy, Cambridge: Cambridge University Press

58 J.H. Dunning and C. Wymbs, 'The geographical sourcing of technological based assets by multinational enterprises', in: Archibugi, D., Howells, J. and Michie, J. (eds), Innovation Systems in a Global Economy, (Cambridge: Cambridge University Press, 1998)

${ }^{59}$ See also the various contributions in M. Berg and K. Bruland (eds), Technological Revolutions in Europe (Aldershot: Edward Elgar, 1998), which provide further evidence in support of this conclusion, from a wider historical perspective. 